\title{
Effect of Hemopurification Rate on Doripenem Pharmacokinetics in Critically III Patients Receiving High-flow Continuous Hemodiafiltration
}

\author{
Yoshifumi OHChI, Seigo HidaKA*, Koji Goto, Ryo Shitomi, \\ Taichi NishIDA, Takakuni ABE, Shunsuke YAMAMOTO, Norihisa YASUdA, \\ Satoshi HAGIWARA, and Takayuki NOGUCHI \\ Department of Anesthesiology and Intensive Care, Faculty of Medicine, Oita University, \\ 1-1 Idaigaoka-Hasamamachi, Yufu, Oita 879-5593, Japan
}

(Received March 11, 2011; Accepted June 24 2011; Published online June 30, 2011)

\begin{abstract}
Hemopurification is an effective therapy for acute kidney injury, defined as creatinine clearance less than $30 \mathrm{ml} /$ min, which occurs frequently in the intensive care unit. These critically ill patients often have severe infectious complications and are thus often treated with antibiotics. However, the effect of hemopurification on the pharmacokinetics of antibiotics is not well understood. In this study, we investigated the pharmacokinetics of doripenem (DRPM) in critically ill patients with accompanying renal dysfunction undergoing continuous hemodiafiltration by high-volume filtration/ high-flow dialysis (high-flow CHDF) and compared it to the pharmacokinetics of DRPM during conventional CHDF. We studied 8 patients ( 2 in the high-flow group and 6 in the conventional group) in whom DRPM was administered while performing CHDF for acute kidney injury. DRPM $(250 \mathrm{mg})$ was intravenously infused over $1 \mathrm{~h}$. For the conventional group, CHDF was performed at a blood flow rate $\left(\mathrm{Q}_{B}\right)$ of $100 \mathrm{ml} / \mathrm{min}$, dialysate flow rate $\left(\mathrm{Q}_{\mathrm{D}}\right)$ of $500 \mathrm{ml} / \mathrm{h}$, and filtration flow rate $\left(\mathrm{Q}_{\mathrm{F}}\right)$ of $300 \mathrm{ml} / \mathrm{h}$. For the high-flow group, CHDF was performed at a blood flow rate $\left(\mathrm{Q}_{\mathrm{B}}\right)$ of 100 $\mathrm{ml} / \mathrm{min}$, dialysate flow rate $\left(\mathrm{Q}_{\mathrm{D}}\right)$ of $1500 \mathrm{ml} / \mathrm{h}$, and filtration flow rate $\left(\mathrm{Q}_{\mathrm{F}}\right)$ of $900 \mathrm{ml} / \mathrm{h}$. For both groups, a polysulfonehemofilter with a membrane area of $1.0 \mathrm{~m}^{2}$ was used. Mean half-life, total body clearance, and clearance via hemodiafiltration of DRPM were $2.9 \mathrm{~h}, 118 \mathrm{ml} / \mathrm{min}$, and $41.9 \mathrm{ml} / \mathrm{min}$, respectively, in the high-flow group, and $7.9 \mathrm{~h}$, $58 \mathrm{ml} / \mathrm{min}$, and $13.5 \mathrm{ml} / \mathrm{min}$ in the conventional group. Clearance via hemodiafiltration increased approximately 3-fold by tripling the hemopurification rate. Therefore, CHDF parameters greatly affected DRPM pharmacokinetics in patients receiving CHDF. These results suggest that clearance via hemodiafiltration increases proportionally to the hemopurification rate. Thus, it is reasonable to conclude that DRPM dose must be increased to $1.0-1.5 \mathrm{~g} / \mathrm{day}$ when performing high-flow CHDF.
\end{abstract}

Key words_ acute kidney injury; antibiotics; hemodiafiltration; pharmacology

\section{INTRODUCTION}

Continuous hemodiafiltration (CHDF) is an important treatment modality in the management of intensive care patients. It is used not only as an organsupporting procedure, but frequently in acute kidney injury, liver failure, severe acute pancreatitis, and sepsis with the goal of improving outcomes secondary to the removal of various disease mediators or other agents. ${ }^{1-4)}$ CHDF removes unnecessary or toxic substances from blood by employing the principles of filtration and dialysis. However, given that substances smaller than the hemopurification membrane pore diameter can non-selectively pass through, substances essential to the well-being of the patient or pharmaceutical agents being used for treatment might be simultaneously removed. ${ }^{5,6)}$ Therefore, determining

\footnotetext{
*e-mail: sehidaka@oita-u.ac.jp
}

proper dosages by clarifying the pharmacokinetics of various pharmaceutical agents in patients receiving CHDF can be extremely useful.

Many patients in need of acute hemopurification have infectious complications that require antibiotic administration. Studies on the pharmacokinetics of one particular antibiotic, the carbapenem antibiotic doripenem (DRPM), while performing conventional $\mathrm{CHDF}^{7,8)}$ have shown that DRPM clearance during CHDF was $13.5 \mathrm{ml} / \mathrm{min}$ using CHDF parameters typically used in Japan (blood flow rate $\left(\mathrm{Q}_{\mathrm{B}}\right) 100 \mathrm{ml}$ / min, dialysate flow rate $\left(Q_{D}\right) 500 \mathrm{ml} / \mathrm{h}$, filtration flow rate $\left.\left(\mathrm{Q}_{\mathrm{F}}\right) 300 \mathrm{ml} / \mathrm{h}\right)$. These results showed that the pharmacokinetics of DRPM depended primarily on residual renal function and that $\mathrm{CHDF}$ had little impact. However, the pharmacokinetics of antibiotics during acute hemopurification under other conditions remains unclear.

Theoretically, DRPM is a drug that should be easi- 
ly removed by filtration/dialysis given its low molecular weight, protein-binding rate, and volume of distribution. ${ }^{9)}$ Clearance is also expected to increase directly with increases in hemopurification rate (filtration flow rate + dialysate flow rate) and thus, there is a high likelihood that dose adjustments based on varying CHDF parameters would be necessary. In recent years, the number of cases in which CHDF by high-volume filtration/high-flow dialysis (high-flow CHDF) is performed for removing toxic substances such as cytokinesis in septic patients. ${ }^{10)}$ Given that an insufficient dose of an appropriate antibacterial agent may be fatal, identification of the proper dosage is important. In this study, we investigated the pharmacokinetics of DRPM in patients receiving highflow CHDF and compared it to that in patients receiving conventional-dose CHDF. ${ }^{7}$ )

\section{SUBJECTS AND METHODS}

Subjects Subjects were two patients who underwent high-flow CHDF. DRPM (Finibax ${ }^{\circledR}$; Shionogi \& Co., Ltd., Osaka, Japan) was administered while performing CHDF for acute kidney injury in the intensive care unit at the Oita University Faculty of Medicine Hospital between November 2006 and March 2009. Before carrying out the study, we obtained written consent from the subjects or close relatives along with approval to conduct the study from the Oita University Faculty of Medicine Ethics Committee.

\section{Methods}

Doripenem Administration and Collection of Blood Samples Six patients (ID 1-6) were described in a previous study. ${ }^{7)}$ Two patients (ID 7, 8) received a single dose of doripenem (250 $\mathrm{mg}$ ). Doripenem (250 mg; Shionogi \& Co., Ltd., Japan) was dissolved in $20 \mathrm{ml}$ of normal saline solution and administered as an intravenous drip over $1 \mathrm{~h} /$ session. Blood samples were collected from an indwelling arterial line in heparinized tubes before doripenem treatment and at 1 (just prior to the end of the infusion period), 2, 3, 4, 7, and $12 \mathrm{~h}$ after initiating the infusion.

Pharmacokinetics of Doripenem Doripenem levels in human plasma were determined by a validated high-performance liquid chromatography (HPLC; Shimadzu 10A series) assay, performed by Mitsubishi Chemical Medience Corporation (Tokyo, Japan). Non-compartmental pharmacokinetic analysis of doripenem was performed. From data on plasma levels of doripenem during the elimination phase, the elimination rate constant $\left(\lambda_{z}\right)$ and the half-life $\left(T_{1 / 2}\right)$ of doripenem during the elimination phase were calculated. Using the trapezoidal method, we calculated the area under the plasma concentration-time curve (AUC) and the distribution volume at steady-state $\left(\mathrm{V}_{\mathrm{dss}}\right)$. From the dose level of doripenem and the AUC, total clearance $\left(\mathrm{CL}_{\mathrm{Total}}=\mathrm{dose} / \mathrm{AUC}\right)$ was calculated. $\mathrm{CHDF}$ clearance $\left(\mathrm{CL}_{\mathrm{CHDF}}\right)$ was calculated using the following equation ${ }^{11)}$ :

$$
\mathrm{CL}_{\mathrm{CHDF}}=\mathrm{Q}_{\mathrm{B}} \times(1-\mathrm{Hct}) \times\left(\mathrm{C}_{\mathrm{in}}-\mathrm{C}_{\text {out }}\right) / \mathrm{C}_{\mathrm{in}} \text {, }
$$

where $\mathrm{Q}_{\mathrm{B}}$ is the blood flow rate, Hct is the hematocrit level, $C_{i n}$ is the plasma concentration of doripenem before the hemofilter, and $\mathrm{C}_{\text {out }}$ is the plasma concentration of doripenem after the hemofilter. The plasma concentration of doripenem at the end of drug administration was considered the maximum plasma concentration $\left(\mathrm{C}_{\max }\right)$.

CHDF Parameters In the present study, a polysulfone hemofilter with a membrane surface area of $1.0 \mathrm{~m}^{2}$ (HEMOFEEL ${ }^{\circledR} \mathrm{SH}-1.0$, Toray Medical, Inc., Japan) was used for hemopurification. High-flow CHDF was performed with a $\mathrm{Q}_{\mathrm{B}}$ of $100 \mathrm{ml} / \mathrm{min}, \mathrm{Q}_{\mathrm{D}}$ of $1500 \mathrm{ml} / \mathrm{h}$, and $\mathrm{Q}_{\mathrm{F}}$ of $900 \mathrm{ml} / \mathrm{h}$. Sublood-BS ${ }^{\circledR}$ (Fuso Pharmacy, Inc., Japan) served as dialysate and substitution fluid. This setting was a higher volume compared to that in a previous study we performed (standard-dose CHDF; $\mathrm{Q}_{\mathrm{B}}$ of $100 \mathrm{ml} / \mathrm{min}$, $\mathrm{Q}_{\mathrm{D}}$ of $500 \mathrm{ml} / \mathrm{h}$, and $\mathrm{Q}_{\mathrm{F}}$ of $\left.300 \mathrm{ml} / \mathrm{h}\right)$. $^{6}$ During CHDF, nafamostatmesilate was serially administered at a rate of $20-30 \mathrm{mg} / \mathrm{h}$ to avoid coagulation within the circuit.

Statistical Analysis Results were expressed as mean \pm standard deviation (S.D.). Statistical analysis was performed with StatView V software (Abacus Concepts, Berkeley, CA).

\section{RESULTS}

Patient Characteristics Demographic and clinical characteristics of individual patients are shown in Table 1. Six patients (ID 1-6) participated in our previous study. ${ }^{7)}$ All patients had severe renal dysfunction, with creatinine clearances $\left(\mathrm{C}_{\mathrm{cr}}\right.$, an indicator of residual renal function) that ranged from 3.7 to $15.0 \mathrm{ml} / \mathrm{min}$ (mean, $9.54 \mathrm{ml} / \mathrm{min}$ ). Residual diuresis was not extensive in any patient during the study period. 
Table 1. Patient Demographic and Clinical Characteristics

\begin{tabular}{c|c|c|c|c|l|c|c}
\hline \hline Patient & Gender & $\begin{array}{c}\text { Age } \\
(\text { years })\end{array}$ & $\begin{array}{c}\text { Weight } \\
(\mathrm{kg})\end{array}$ & $\begin{array}{c}\mathrm{C}_{\mathrm{cr}} \\
(\mathrm{ml} / \mathrm{min})\end{array}$ & \multicolumn{1}{|c|}{ Diagnosis on admission } & APACHE II* & SOFA** \\
\hline ID-1 & $\mathrm{M}$ & 63 & 52 & 6.7 & Ileus, sepsis & 26 & 13 \\
\hline ID-2 & $\mathrm{M}$ & 74 & 56 & 12.0 & Ruptured abdominal aortic aneurysm & 26 & 14 \\
\hline ID-3 & $\mathrm{F}$ & 59 & 52 & 9.8 & Pneumonia, sepsis & 23 & 12 \\
\hline ID-4 & $\mathrm{F}$ & 68 & 62 & 6.9 & Pyodermagangrenosum, sepsis & 12 & 12 \\
\hline ID-5 & $\mathrm{M}$ & 56 & 73 & 3.7 & Aortic and mitral valve replacement & 28 & 13 \\
\hline ID-6 & $\mathrm{F}$ & 84 & 52 & 15.0 & Dissecting thoracic aortic aneurysm & 26 \\
\hline ID-7 & $\mathrm{M}$ & 73 & 67 & 13.5 & Coronary artery bypass grafting & 21 & 11 \\
\hline ID-8 & $\mathrm{M}$ & 65 & 55 & 8.7 & Aorticvalve replacement & 20 & 10 \\
\hline
\end{tabular}

* Acute Physiology and Chronic Health Evaluation II. ** Sequential Organ Failure Assessment; $\mathrm{C}_{\mathrm{cr}}$, creatinine clearance. Data from patients ID 1-6 were reported in our previous study. ${ }^{7)}$

Table 2. Pharmacokinetic Parameters of Doripenem: Comparison between Patients Receiving CHDF and Individuals with Various Degrees of Renal Function

\begin{tabular}{|c|c|c|c|c|}
\hline Type of individual & $\begin{array}{c}\mathrm{AUC}^{b} \\
(\mathrm{mg} \cdot \mathrm{h} / \mathrm{l})\end{array}$ & $\begin{array}{l}\mathrm{CL}_{\text {total }}{ }^{c} \\
(\mathrm{ml} / \mathrm{min})\end{array}$ & $\begin{array}{l}\mathrm{CL}_{\mathrm{CHDF}}{ }^{d} \\
(\mathrm{ml} / \mathrm{min})\end{array}$ & $\mathrm{T}_{1 / 2}{ }^{e}(\mathrm{~h})$ \\
\hline $\begin{array}{l}\text { Conventional CHDF } \\
\text { patients }(n=6)^{7)}\end{array}$ & $74.6 \pm 15.6$ & $58 \pm 12.7$ & $13.5 \pm 1.6$ & $7.9 \pm 3.7$ \\
\hline $\begin{array}{l}\text { High-flow CHDF } \\
\text { patients }(n=2)\end{array}$ & 35.2 & 118 & 41.9 & 2.9 \\
\hline $\begin{array}{l}\text { Group I }(n=2)^{12)} \\
\mathrm{C}_{\mathrm{cr}}{ }^{a}<30 \mathrm{ml} / \mathrm{min}\end{array}$ & 64.3 & 65 & - & 3.6 \\
\hline $\begin{array}{l}\text { Group II }(n=6)^{12)} \\
\mathrm{C}_{\mathrm{cr}}{ }^{a} 30-50 \mathrm{ml} / \mathrm{min}\end{array}$ & $48.2 \pm 13.4$ & $93 \pm 29.2$ & - & $2.2 \pm 0.3$ \\
\hline $\begin{array}{l}\text { Group III }(n=4)^{12)} \\
\mathrm{C}_{\mathrm{cr}}{ }^{a} \geq 50 \mathrm{ml} / \mathrm{min}\end{array}$ & $40.6 \pm 5.9$ & $104.3 \pm 15.2$ & - & $2.0 \pm 0.4$ \\
\hline $\begin{array}{l}\text { Control Group } \\
(n=6)^{12)}\end{array}$ & $20.3 \pm 3.5$ & $209.8 \pm 29.5$ & - & $0.9 \pm 0.1$ \\
\hline
\end{tabular}

Data are expressed as mean \pm standard deviation (S.D.) when the number of individuals is more than 2 . Data on high-flow CHDF patients are from the current study. Data on conventional CHDF patients were reported in a previous study. ${ }^{7)}$ Data on groups I, II, III, and controls were previously reported by Uehara S., et al. ${ }^{12)}{ }^{a}$ creatinine clearance; ${ }^{b}$ area under the curve; ${ }^{c}$ total doripenem clearance; ${ }^{d}$ doripenem clearance by $\mathrm{CHDF} ;{ }^{e}$ elimination half-life.

\section{Pharmacokinetics}

\section{Time Course of Plasma DRPM Concentration}

Figure 1 shows a time course of plasma doripenem concentrations after the first dose in the standard- and high-flow groups. Although plasma concentrations decreased with time for both groups, the decrease was faster in the high-flow group compared to the standard-dose group.

Pharmacokinetic Parameters Table 2 presents the pharmacokinetic parameters for doripenem, calculated from the plasma concentration in patients receiving CHDF in the current study. In the high-flow group (ID 7-8), the AUC was $35.2 \mathrm{mg} \cdot \mathrm{h} / \mathrm{l}, \mathrm{T}_{1 / 2}$ was

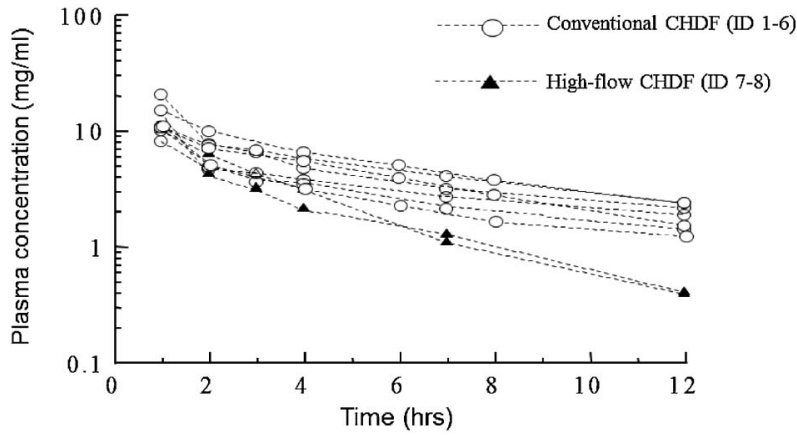

Fig. 1. Plasma Concentration-time Profiles of Doripenem Symbols: $\bigcirc$, conventional CHDF; $\boldsymbol{\Lambda}$, high-flow CHDF. Data for conventional $\mathrm{CHDF}$ were reported in a previous study. ${ }^{7)}$ 
$2.9 \mathrm{~h}, \mathrm{CL}_{\text {TOT }}$ was $118 \mathrm{ml} / \mathrm{min}$, and $\mathrm{CL}_{\mathrm{CHDF}}$ was 41.9 $\mathrm{ml} / \mathrm{min}$. In the conventional group (ID 1-6), the AUC was $74.6 \pm 15.6 \mathrm{mg} \cdot \mathrm{h} / \mathrm{l}, \mathrm{T}_{1 / 2}$ was $7.9 \pm 3.7 \mathrm{~h}$, $\mathrm{CL}_{\text {TOT }}$ was $58 \pm 12.7 \mathrm{ml} / \mathrm{min}$, and $\mathrm{CL}_{\mathrm{CHDF}}$ was $13.5 \pm$ $1.6 \mathrm{ml} / \mathrm{min}$. In the high-flow group, $\mathrm{CL}_{\mathrm{CHDF}}$ increased approximately 3-fold after tripling the hemopurification rate compared to the conventional group. Pharmacokinetic parameters of doripenem in the high-flow group were similar to that observed in patients with $\mathrm{C}_{\mathrm{cr}}>50 \mathrm{ml} / \mathrm{min}$, as reported in a previous clinical study. ${ }^{12)}$

\section{DISCUSSION}

Acute kidney injury is a frequently observed condition in the intensive care unit. Although CHDF is frequently performed as renal support therapy for acute renal failure, the pharmacokinetics of various drugs are very different from normal because the administered drugs are removed by filtration and dialysis. For this reason, it is difficult to establish proper drug dosage. ${ }^{13)}$ If pharmaceutical agents administered for treatment purposes accumulate in the body, this could lead to additional organ damage; if the effective blood concentration is not reached, the treatment might not be effective. In particular, caution is necessary in patients with severe infections because an insufficient dose of an antibacterial agent could be fatal.

In a previous study, ${ }^{7)}$ we examined the pharmacokinetics of doripenem in patients receiving CHDF. The CHDF settings employed at the time were within the range of $\mathrm{CHDF}$ replacement fluid (Sublood-BS ${ }^{\circledR}$ ) that could be used under health insurance treatment guidelines in Japan, where $Q_{D}$ was $500 \mathrm{ml} / \mathrm{h}$ and $\mathrm{Q}_{\mathrm{F}}$ was $300 \mathrm{ml} / \mathrm{h}$. The results for these settings, which we designated as the conventional mode, were a $T_{1 / 2}$ of $7.9 \pm 3.7 \mathrm{~h}$, a $\mathrm{CL}_{\text {Tот }}$ of $58 \pm 12.7 \mathrm{ml} / \mathrm{min}$, and a $\mathrm{CL}_{\mathrm{CHDF}}$ of $13.5 \pm 1.6 \mathrm{ml} / \mathrm{min}$. These results indicated that pharmacokinetics of doripenem were primarily dependent on residual renal function and that $\mathrm{CHDF}$ involvement was minor. Therefore, we concluded that it was not necessary to increase the dose, even while performing $\mathrm{CHDF}$, and that it was possible to control the blood concentration by adjusting the dosage and dosing interval in accordance with residual renal function. However, in this study, hemopurification rate had an effect on doripenem pharmacokinetics when the rate was higher than that in the previous study. The fact that more doripenem was removed suggests that more doripenem must be administered under these conditions.

Doripenem is a renally excreted drug with a molecular weight of $438 \mathrm{Da}$, a protein binding rate of 6-9 $\%$, and a $75 \%$ (24 h) unchanged drug urinary excretion rate. ${ }^{14)}$ For this reason, dosages are typically established according to the patient's renal function. Its protein-binding rate is low, and it is generally thought to be readily removed by dialysis and filtration. Accordingly, it is likely that these results are largely due to CHDF parameters. In this study, we examined the pharmacokinetics of doripenemunder a high-flow mode $\left(Q_{D} 1500 \mathrm{ml} / \mathrm{h}, \mathrm{Q}_{\mathrm{F}} 900 \mathrm{ml} / \mathrm{h}\right)$ that tripled the previous hemopurification rate. $\mathrm{T}_{1 / 2}$ was $2.9 \mathrm{~h}, \mathrm{CL}_{\mathrm{TOT}}$ was $118 \mathrm{ml} / \mathrm{min}$, and $\mathrm{CL}_{\mathrm{CHDF}}$ was $41.9 \mathrm{ml} / \mathrm{min}$. The results showed that $\mathrm{CL}_{\mathrm{CHDF}}$ increases in proportion with the hemopurification rate. $\mathrm{CL}_{\mathrm{CHDF}}$ was $13.5 \mathrm{ml} /$ min in the conventional mode $\left(Q_{D} 500 \mathrm{ml} / \mathrm{h}+\mathrm{Q}_{\mathrm{F}} 300\right.$ $\mathrm{ml} / \mathrm{h}$; estimated creatinine clearance of $13 \mathrm{ml} / \mathrm{min}$ ) and $41.9 \mathrm{ml} / \mathrm{min}$ in the high-flow mode $\left(\mathrm{Q}_{\mathrm{D}} 1500 \mathrm{ml} /\right.$ $\mathrm{h}+\mathrm{Q}_{\mathrm{F}} 900 \mathrm{ml} / \mathrm{h}$; estimated creatinine clearance of 40 $\mathrm{ml} / \mathrm{min}$ ). In both cases, $\mathrm{CL}_{\mathrm{CHDF}}$ was nearly the same as the creatinine clearance rate estimated from the hemopurification rate. Therefore, it is likely that $\mathrm{CL}_{\mathrm{CHDF}}$ of doripenem can be predicted from the hemopurification rate and that when performing high-flow CHDF, it will be necessary to establish dosages taking into account $\mathrm{CL}_{\mathrm{CHDF}}$ and residual renal function.

According to the drug package insert, the established upper limits of doripenem dosage for patients with $\mathrm{C}_{\mathrm{cr}}$ of less than $30 \mathrm{ml} / \mathrm{min}, 30-50 \mathrm{ml} / \mathrm{min}, 50-70$ $\mathrm{ml} / \mathrm{min}$, and more than $70 \mathrm{ml} / \mathrm{min}$ is $0.5,0.75,1.0$, $1.5 \mathrm{~g} /$ day, respectively. Based on the results of this study, given that a greater amount of doripenem is excreted from the body during high-flow CHDF, the daily dose must be increased to $1.0-1.5 \mathrm{~g}$, the same dosage used for patients with $\mathrm{C}_{\mathrm{cr}}>50 \mathrm{ml} / \mathrm{min}$. Since 2000, when Ronco C., et al. reported that hemodynamics and prognosis improved as a result of increasing the hemopurification rate, ${ }^{15)}$ cases in which high-flow CHDF is performed to remove various mediators have increased in Japan. In particular, there are sporadic reports of its utility in the acute management of severe sepsis. ${ }^{4,9)}$ However, given that administration of a sufficient amount of antibacterial agent is indispensable in the initial stages of treating the infection, ${ }^{16)}$ care must be taken to adjust the dosage in accordance with $\mathrm{C}_{\mathrm{LCHDF}}$. 
One limitation of this study is that the number of subjects analyzed is small. Another limitation is that we used a polysulfone hemofilter that does not have adsorption properties. Since we only investigated drug removal by dialysis filtering, the results may differ in situations where other types of hemofilters, such as those with adsorption properties, are used.

In conclusion, our results indicate that $\mathrm{CHDF}$ parameters may have a significant impact on the pharmacokinetics of doripenem in patients receiving $\mathrm{CHDF}$, and that $\mathrm{CL}_{\mathrm{CHDF}}$ increases in proportion to the hemopurification rate. The $\mathrm{CL}_{\mathrm{CHDF}}$ of DRPM in the high-flow mode was $41.9 \mathrm{ml} / \mathrm{min}$. Thus, although the upper limit of the dosage for patients with $\mathrm{C}_{\mathrm{cr}}$ less than $30 \mathrm{ml} / \mathrm{min}$ is $0.5 \mathrm{~g} /$ day according to the drug package insert, the limit must be increased to $1.0-1.5$ $\mathrm{g}$ /day when performing high-flow CHDF.

\section{REFERENCES}

1) Murray P., Hall J., Am. J. Respir. Crit. Care Med., 162, 777-781 (2000).

2) Sadahiro T., Hirasawa H., Oda S., Shiga H., Nakanishi K., Kitamura N., Hirano T., Crit. Care Med., 29, 1386-1392 (2001).

3) Jiang H. L., Xue W. J., Li D. Q., Yin A. P., Xin X., Li C. M., Gao J. L., World J. Gastroenterol., 11, 4815-4821 (2005).

4) Honore P. M., Jamez J., Wauthier M., Lee P. A., Daugernier T., Pirenne B., Hanique G., Matson J. R., Crit. Care Med., 28, 3581-3587 (2000).

5) Thalhammer F., Schenk P., Burqmann H., El Menyawi I., Hollenstein U. M., Rosenkranz A. R., Sunder-Plassmann G., Breyer S., Ratheiser K., Antimicrob. Agents Chemo- ther., 42, 2417-2420 (1998).

6) Hayakawa M., Ito Y., Fujita I., Iseki K., Gando S., ASAIO J., 52, 398-403 (2006).

7) Hidaka S., Goto K., Hagiwara S., Iwasaka H., Noguchi T., Yakugaku Zasshi, 130, 87-94 (2010).

8) Hidaka S., Goto K., Matsumoto S., Oyama T., Yamamoto S., Yasuda N., Hagiwara S., Shingu C., Iwasaka H., Noguchi T., Rinsho to Biseibutsu, 35, 199-203 (2008) .

9) Cotterill S., J. Antimicrob. Chemother., 36, 773-780 (1995).

10) Ratanarat R., Brendolan A., Piccinni P., Dan M., Salvatori G., Ricci Z., Ronco C., Crit. Care, 9, 294-302 (2005).

11) Kishino S., Takekuma Y., Sugawara M., Shimamura T., Furukawa H., Todo S., Miyazaki K., J. Chromatogr. B Analyt. Technol. Biomed. Life Sci., 780, 289-294 (2002).

12) Uehara S., Mura W., Seno Y., Andoh E., Monden K., Kariyama R., Tsugawa M., Nakashima M., Kumon H., Jpn. J. Chemother., 53, 130-135 (2005).

13) Boereboom F. T., Ververs F. F., Blankestijn P. J., Savelkoul T. J., van Dijk A., Intensive Care Med., 25, 1100-1104 (1999).

14) Nakashima M., Oguma T., Jpn. J. Chemother., 53, S104-123 (2005).

15) Ronco C., Bellomo R., Homel P., Brendolan A., Dan M., Piccini P., La Greca G., Lancet, 356, 26-30 (2000).

16) Kumar A., Roberts D., Wood K. E., Light B., Parrillo J. E., Sharma S., Suppes R., Zanotti S., Taiberg L., Gurka D., Cheang M., Crit. Care Med., 34, 1589-1596 (2006). 